\title{
Symptoms of Wear HSS Cutting Tools in Different Wear Stages
}

\author{
Marcin Paprocki (0000-0001-7282-5421)1, Mateusz Wygoda (0000-0003-4911-727X)1, Paweł Wyczesany (0000- \\ 0002-5871-9144) ${ }^{1}$, Patrycja Bazan (0000-0002-5442-3119)2 \\ 1 Department of Product Technology and Ecology, College of Management and Quality Sciences, Cracow Uni- \\ versity of Economics. Rakowicka 27, 31-510 Kraków. Poland. E-mail: paprockm@uek.krakow.pl, \\ wygodam@uek.krakow.pl,wyczesap@uek.krakow.pl \\ 2Institute of Materials Engineering, Faculty of Materials Engineering and Physics, Cracow University of Techno- \\ logy. al. Jana Pawła II 37, 31-864 Kraków. Poland. E-mail: patrycja.bazan@gmail.com
}

Planning a process of production, among other machining processes, is an important stage in the production of products. The developed machining process should allow production of parts with the planned dimensional accuracy and specified surface roughness. With reference to the above, the scope of the carried out theoretical work included determining the dependences between parameters of the drilling process, tool wear, as well as the impact of these parameters on the hole quality. The main aim of experimental research was to analyse cutting tools wear in various phases of tool usage. The research consisted in observation of metallographic microsections to analyse changes occurring in the drill bit microstructure. Then the microhardness was measured and in the next step the microhardness of the tested drills was statistically compared. Based on the results obtained, the percentage of wear for drill bits depending on microhardness was estimated taking into account the earlier estimated Percentable Production Cycle $\left(\mathbf{P}_{\mathrm{PC}}\right)$. This allowed determining the degree of wear and tear of drills by comparing the microstructure and microhardness between them. The aspects of cutting tool management are also discussed.

Keywords: cutting tool management, drill bit, wear, hole quality, microstructure, microhardness, percentable production cycle ( $\left.\mathrm{P}_{\mathrm{PC}}\right)$

\section{Introduction}

In many industries the structural components (parts) of devices and machinery are made by machining. Machining is aimed at shaping appropriate geometry and surface roughness of a workpiece. This enables not only appropriate dimensions but also intended surface layer condition to be reached [1]. Depending on the assumed requirements for intended use of the component being machined, and consequently the achieved dimensional accuracy and surface roughness, machining can be divided into rough, shape and finish machining. Considering the above it into: rough, shape, is also possible to divide machining into rough, shape, precise and high precision machining or into rough, medium, high precision machining and honing.

When machining holes drill bits are most commonly used. Their geometry and material they are made of have an important impact on quality of machining operations [2, 3]. This paper deals with HSS (High Speed Steel) drill bits due to its common usage and low purchasing costs. The main features of HSS drill bits are shown in Tab. 1.

Tab. 1 Comparison of HSS drill bit technological, economic and quality parameters [4]

\begin{tabular}{|c|c|}
\hline Price & Low \\
\hline Durability & Relatively short \\
\hline $\begin{array}{c}\text { Regeneration capa- } \\
\text { bility }\end{array}$ & Can be re-sharpened \\
\hline $\begin{array}{c}\text { Machining quality } \\
\text { Productivity }\end{array}$ & $\begin{array}{c}\text { Relatively low (necessity of pre-drilling (drilling a pilot hole) before machining and } \\
\text { reaming to H7 tolerance) }\end{array}$ \\
\hline
\end{tabular}

\section{Factors influencing drilled-hole quality}

In a technological process drilled-hole quality, i.e. hole size, surface roughness $(\mathrm{Ra})$, roundness and radial deviation, is affected by drilling (machining) parameters such as cutting speed, feed rate, drill bit wear, both low and high frequency vibrations that occur during drilling [5]. In addition to said drilling parameters also 
the condition of cutting tool, i.e. degree of wear, decides on hole quality. When number of holes drilled is increased, the cutting tool loses its original properties. Therefore, after a specified (expected) running time, the tool should be replaced or regenerated to maintain appropriate drilled-hole quality (i.e. proper dimensional accuracy and roughness level).

In [6] to evaluate the dimensional accuracy for holes made with countersink drill bits the following measurements were made: drilled-hole diameter and cylindricity deviations and perpendicularity deviations from the front face and coaxiality deviations from the round spigot. During material removal processing, keep in mind that it is necessary to follow and monitor the selected and preset machining parameters, as this has an important effect of the quality of workpiece.

The symptoms of tool wear may include deformations in the form of changes in tooth shape and geometry, loss of tool material, fractures, build-up edges as well as changes in surface layer properties [7, 8]. Excessive wear of drill bits is connected with the cutting zone temperature rise to a value that changes the basic properties of the tool.

This is demonstrated by worsening hole quality parameters, working surface condition, dimensional accuracy and occurrence of shiny or colour smears on the workpiece surface [8]. With increasing degree of wear of tooth, the frictional moment on minor cutting surfaces increases, generating a temperature rise, thus causing thermal deformation of the workpiece. Whereby the drilled holes are deformed in such a way that its diameter decreases [9]. The cutting edge wear also affects the form and shape of chips produced in such a way that the chip is discontinuous over its length [7].

According to indicative temperature distribution in cutting edge, chip and workpiece when turning steel with the depth of cut $\mathrm{a}_{\mathrm{p}}=0.32[\mathrm{~mm}]$ the extreme temperature difference between the chip $\left(348^{\circ} \mathrm{C}\right.$, minimum) and the cutting tool $\left(700^{\circ} \mathrm{C}\right.$, maximum) reaches up to $352^{\circ} \mathrm{C}$. Such high temperatures require that cutting tools have the following two properties, namely heat resistance achievable by such alloy additives as: $\mathrm{Cr}, \mathrm{Si}, \mathrm{Al}$, and creep resistance due to alloy additives: $\mathrm{Ni}, \mathrm{Mo}, \mathrm{W}, \mathrm{V}, \mathrm{Co}, \mathrm{Cr}$, Ti and Si. By fulfilling these conditions, it is possible to prevent to a great extent said unfavourable phenomena occurring in the machining process [10].

\section{Factors influencing cutting edge wear}

Properly chosen drilling process parameters, e.g. cutting speed $\mathrm{V}_{c}$, have a large effect on wear of drill bits. The use of the right coolant when drilling has a significant effect on drill bit wear rate slow down by preventing excessive temperature rise on the tool at the cutting zone $[11,12,13,14]$.
Analysing the machining process, the occurrence of unfavourable phenomena accompanying the wear of cutting edges can be outlined. Assuming that a cutting tool is properly used, the following main causes of wear can be indicated [15, 16, 17, 18, 19]:

1 - mechanical wear - this is particularly noticeable when machining hard materials and materials containing hard inclusions. Consequently, the generated chip participates in the abrasion process on the rake and flank faces, which translates into cutting edge material removal. This leads to cutting edge dulling.

2 - adhesion - the build-up edge is formed by ,welding" particles of the workpiece material onto the cutting edge. The binding force is so high that when removing the build-up edge, the cutting edge material is also removed.

3 - diffusion - the high temperature allows particles and atoms on one material to diffuse into another material. The chip that rubs against the rake face at a high temperature and under high pressures, adheres very strongly to this face.

4 - oxidation occurs at the chip-cutting edge interface (high temperature, air exposure). Crater wear occurs (narrow gouges, scratches on the rake and flank faces perpendicular to the cutting edge).

5 - plastic deformations - high temperatures are generated at high speeds at the tool-workpiece interface. While considering considerable pressures and the use of large tool feeds it is possible that so called plastic deformations of tools occur (high speed steels).

Assuming a constant cutting time, depending on the cutting speed a different wear rate of cutting edge can be observed for individual types of wear. Generally, the higher cutting speed, the higher wear rate of cutting edge. However, adhesive wear rate increases at small feeds and rotational speeds (for high speed steel tools), and then decreases with increasing cutting speed [20].

\section{Wear of drill bits and the quality of drilling process and drilled holes}

In this section, the aim of the review of the literature is directed the relationships between parameters of tech-nological process on the quality condition of the drilling wear and parameters dependend by the two mentioned relations on thequality paramteres of the holes. The parameters of drill bits used have an effect on both the quality of drilled hole and of drilling process. According to [21] an exemplary effect of wear of worn-out tool on the following aspects:

- Economic - in the form of longer operating time, increased power consumption resulting in excessive heat generation, and vibrations affecting the machine technical condition over time. 
- Technological - through higher hole surface roughness (eg. build-up edges - welding the chip onto the cutting edge due to diffusion processes and the occurrence of additional cutting edges, thus leading to a real metalmetal contact), dimensional accuracy (tool deformation).

- Toughness - tool wear causes tool chipping or deformations.

In turn, the drilling process parameters (e.g. cutting speed) have an effect on the drill bit wear rate and type. At the same time, the drilling process parameters influence the drilled hole quality. Interaction of drilling quality parameters and drill bit wear parameters and their impact on drilled hole quality is presented in Fig. 1.

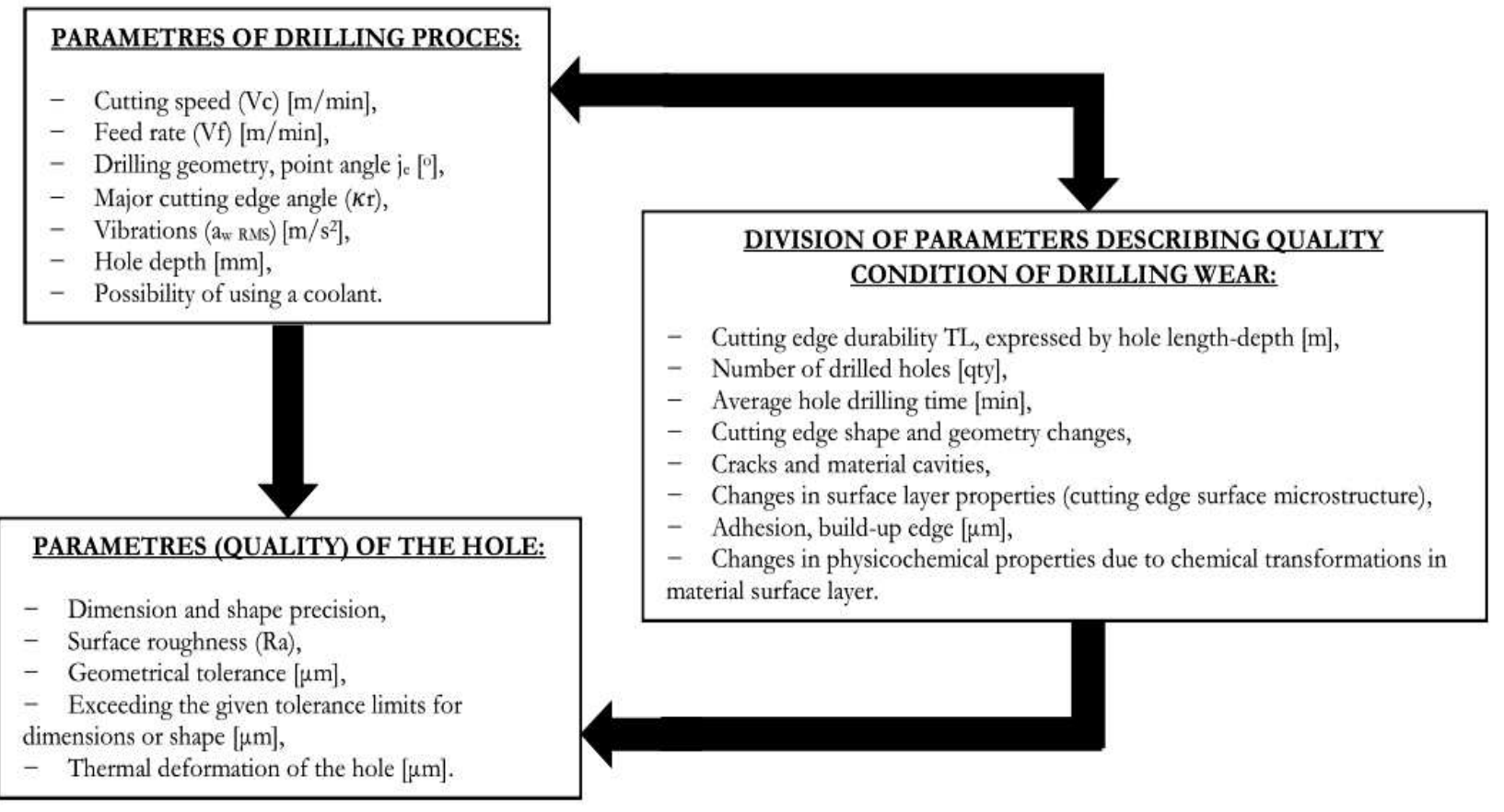

Fig. 1 Relationships between wear of drill bits and the quality of the drilling process and machined holes

\section{Aspects of cutting tool management}

The opportunities to reduce tool operating costs come down to proper tool selection and design, method for manufacturing the tool and working conditions in the workplace as well as to planning of worn-out tool replacement with new ones (or regeneration). All the above is connected with an appropriate tool management system in a manufacturing plant.

It should also be considered if the costs of tool regeneration, including drill bits, are higher or comparable to those of the purchase of new ones. Proper regeneration carried out by removing the surface layer and renewing the right tool geometry assures proper machining parameters. Such tools with regeneration capability reduce operating cost of the machining work centre. From an operational point of view, this is more cost-effective than the purchase of new tools. Tool regeneration can be carried out in-house, provided that an appropriate equipment and qualified personnel are available, or by hiring a company outside the company (e.g. a company that distributes a particular type of tools, or a specialised workshop). This is what makes the use of machining work centre costcompetitive.

The main principle is to select and design a tool that fulfils conditions defined by a technological operation or treatment, and is highly durable and efficient to keep operating costs as low as possible [22, 23]. For this purpose, the following relationships and recommendations [3] can be specified:

- Use of expensive materials only and exclusively for cutting edges.

- Use of replaceable cutting edges that wore out very fast during machining operations.

- Use of typical and standardized designs - thus enabling continuous and trouble-free availability in the tool market.

- Use of tools with regeneration capability (e.g. by sharpening).

However, special attention should be paid to drilling small holes with diameters up to $1 \mathrm{~mm}$. Such operation is referred to as microdrilling. When choosing 
and using such special purpose tools there is a significant problem with tool life estimation. This is caused by too high load with respect to tool strength. In such cases, determination of drilling parameters performs a specific function. Thus, it is important to choose the right drill bit material, machining geometry, cooling and drill chucks. Even slight failure to meet process requirements or change in set parameters may damage the tool [24].

Effective tool management in the company, in a wider sense, should be connected with the rational management of machinery park. Achieving these goals may be supported by Total Productive Maintenance (TPM).

The principal pillars of TPM include $[25,26]$ :

-Autonomous maintenance - to create autonomous maintenance teams responsible for improving the machinery park efficiency.

- Improvement - focusing on continuous improvement to reduce problems arising on machinery and equipment owned by a company, and looking for ways to improve work performance and quality.

- Planned maintenance - forming the habit of caring for machinery and equipment through scheduled inspections and maintenance.

- Planning a new machinery, equipment and tools - rational investment planning related to machinery park based on an analysis of gathered data to decide on purchasing new machinery, equipment and tools, if really required.

- Quality assurance - an analysis of reason of production rejects and striving for reducing the number of rejects.

- Training - operators learn skills to maintain and repair machinery so that they can perform less complex repairs on their own.

- Machinery park management - standardisation and maintenance of good practices. The first step in machinery park management is to perform criticality of machinery and equipment.

- Safety, health and environment - care about workplace safety and an impact of technical equipment on work environment.

To optimise the machinery and tool management in enterprises the computer aided enterprise resource management systems (Enterprise Resourcing Planning - ERP) can be used. The above optimisation can be fostered by integration of the ERP system with the Manufacturing Execution System (MES).

\section{An analysis of changes in drill bit microstructure}

The aim of experimental research is analysing of cutting tools wear changes in various phases of tool usage. The presented approach is mainly directed on the description of the tool condition in given phase of process, microsctucture changes and relations bewteen selected tools. The study was carried out on HSS drill bits $(\mathrm{d}=12[\mathrm{~mm}])$ made of cobalt steels (Stalco Perfect) according to DIN 338 with the point angle of $\alpha=135\left[^{\circ}\right]$ and modified land wear with significantly reduced surface area to allow drilling without a centre punch. Modifications made enable drilling to be made in plates and thin components. The chosen drill bits are used to drill holes in rigid PVC profiles reinforced by hot-dip galvanized steel channel section (Fig. 2). The mentioned process is one of several dozen during PVC windows manufacturing.

These drilled holes are provided for mounting window fittings, corners and espagnolette bars. The thickness of the first ply of drilling is approximately $\mathrm{t}_{\mathrm{PVC}}=2.1[\mathrm{~mm}]$ of PVC profile and secend ply $\mathrm{t}_{\text {steel }}=2.0$ $[\mathrm{mm}]$ of steel reinforcement. The specification of PVC and steel are presented in Tab. 2. The hardness of the materials is not considered due to an order of magnitude difference between the hardness range of the materials.

Experimental examinations were carried out on HSS drill bits made of cobalt steels (Stalco Perfect) in four different phases of tool usage and wear. For all drill bits under investigation the MacAllister 500W pillar drill was used. The parameters of machining process are presented in Tab. 3 .

The chosen tools with different degree of wear were taken from the production line. The one drill use cyclce is estimated on $\mathrm{N}_{\mathrm{c}}=800$ repetitions performed in the production run for a week (5 days) of work. After this time tools are replaced with the news one. The degree of wear in Percentable Production Cycle $\left(\mathrm{P}_{\mathrm{PC}}\right)$ is described as (1) for drill samples (A, B, C):

$$
P_{P C}=\frac{N_{d H}}{N_{C}} \cdot 100 \%
$$

A detailed description of the wear stages of considered drills in the tests, taking into account the number of holes made during drilling and the percentage of production cycle (except for the $\mathrm{D}$ drill), is presented in Tab. 4. 

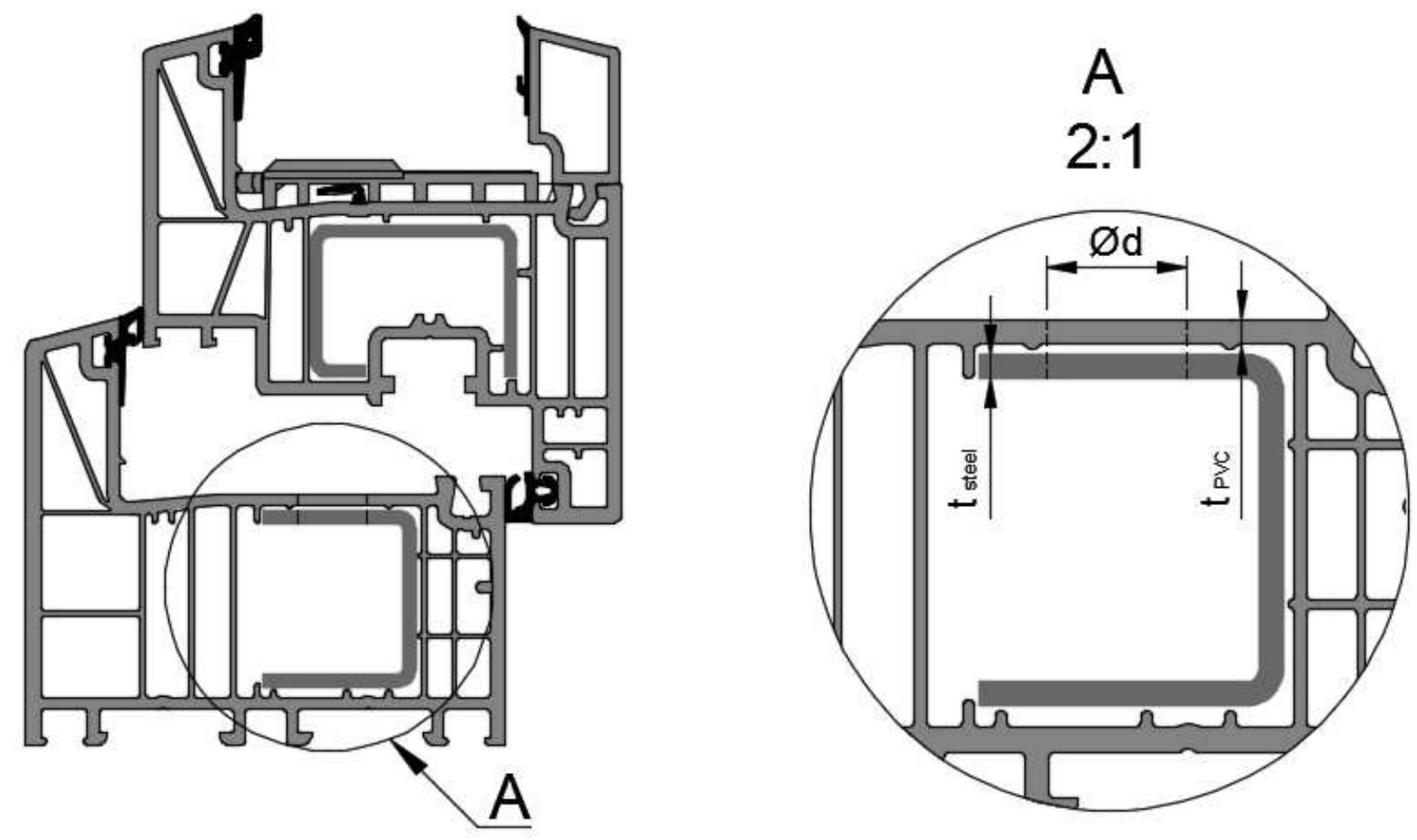

Fig. 2 PVC window sash and frame cross section (grey) and rubber seal (black) and steel reinforcement DX51D (red) - own research based on [27]

Tab. 2 Specification of machining materials according to the available databases [28]

\begin{tabular}{|c|c|c|c|c|c|}
\hline & $\mathbf{Q}\left[\mathbf{g} / \mathbf{c m}^{\mathbf{2}}\right]$ & $\mathbf{E}[\mathbf{G P a}]$ & $\mathbf{R}_{\mathrm{m}}[\mathbf{M P a}]$ & $\mathbf{R}_{\mathrm{e}}[\mathbf{M P a}]$ & A [\%] \\
\hline Rigid PVC (profile) & $1.35-1.50$ & $2.4-4.0$ & $35-60$ & $35-50$ & $25-80$ \\
\hline $\begin{array}{c}\text { Steel DX51D (reinforcement of } \\
\text { PVC) }\end{array}$ & 7.90 & 210 & $270-500$ & $\geq 140$ & $\geq 22$ \\
\hline
\end{tabular}

Tab. 3 Parameters of machining process

\begin{tabular}{|c|c|c|c|c|c|c|c|c|c|}
\hline $\begin{array}{c}\text { Parame- } \\
\text { ters } \\
\text { [units] }\end{array}$ & $\begin{array}{c}\boldsymbol{~} \mathbf{d} \\
{[\mathbf{m m}]}\end{array}$ & $\begin{array}{c}\mathbf{t}_{\text {pvc }} \\
{[\mathrm{mm}]}\end{array}$ & $\begin{array}{c}\mathbf{t}_{\text {steel }} \\
{[\mathrm{mm}]}\end{array}$ & $\begin{array}{c}\mathbf{V c} \\
{[\mathbf{m} / \mathbf{m i n}]}\end{array}$ & $\begin{array}{c}\mathbf{f}_{\mathbf{n}} \\
{[\mathbf{m m} / \mathbf{o b r}]}\end{array}$ & $\begin{array}{c}\mathbf{V}_{\mathbf{f}} \\
{[\mathbf{m m} / \mathbf{m i n}]}\end{array}$ & $\begin{array}{c}\mathbf{f}_{\mathbf{z}} \\
{[\mathbf{m m}]}\end{array}$ & $\begin{array}{c}\mathbf{n} \\
{[\mathbf{r p m}]}\end{array}$ & $\begin{array}{c}\mathbf{z} \\
{[-]}\end{array}$ \\
\hline Value & 12 & 2.1 & 2.0 & 20 & 0.2 & 106 & 0.1 & 530 & 2 \\
\hline
\end{tabular}

where: $d$ - diameter of drill, dh PVC - length of hole in PVC, dh steel - length of hole in steel, Vc - cutting speed, fn - feed per revolution, Vf-penetration rate, fz-feed per blade, $n$-spidle speed, $z$ - number of blades

Tab. 4 Description of drills used to study of microstructure and microhardness

\begin{tabular}{|c|c|c|c|}
\hline Sym. & $\begin{array}{c}\text { Number of drilled } \\
\text { holes } \\
\mathbf{N}_{\mathrm{dH}}[-]\end{array}$ & $\begin{array}{c}\text { Percentable Production } \\
\text { Cycle } \\
\text { P } \\
\text { PC }[\%]\end{array}$ & Short description \\
\hline A & 0 & 0 & Brand-new drill bit \\
\hline B & 200 & 25 & $\begin{array}{l}\text { Used drill bit, slightly worn-out - intended for } \\
\text { regeneration }\end{array}$ \\
\hline $\mathrm{C}$ & 800 & 100 & $\begin{array}{l}\text { Used drill bit, worn-out to a large degree - in- } \\
\text { tended for regeneration due to dulling, axial de- } \\
\text { formation and significant heating up during hole } \\
\text { drill. }\end{array}$ \\
\hline $\mathrm{D}$ & - & - & $\begin{array}{l}\text { Used drill bit - sudden and accelerated loss of } \\
\text { properties, misused in a concrete - material har- } \\
\text { der than specification of drill bit, unsuitable for } \\
\text { drilling holes, non regenerable. }\end{array}$ \\
\hline
\end{tabular}


The taken drill bits respectively denoted by (B), (C) and (D) had characteristic discolorations visible on the surface. The temperature measurement was not carried out due to the impossibility of placing the measuring device inside welded PVC frame. However, the occurrence of said discolorations on the tool surface indicates that the tool worked at high temperature [29, 30].

To perform microstructure study choosen four tools in different stage of wear described in Tab. 4. The main interesting part of the drill is the frontal working part in the place of blade surface. These samples are taken by cutting off the part of drill bit approximately $30 \mathrm{~mm}$ above the cutting edge to be examined. The distance of cutting prevents blade surface of drill from the heat-influence and artificial microstructure changes - the sampling scheme is presented in the Fig. 3.
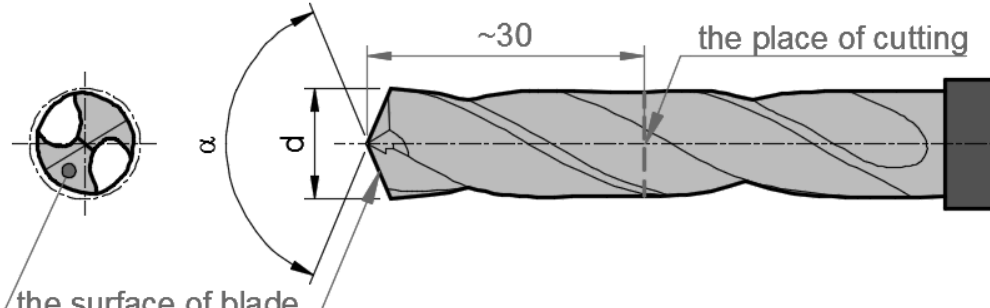

the surface of blade

provided to testing

Fig. 3 Illustration of the exemplayer of the drill sample

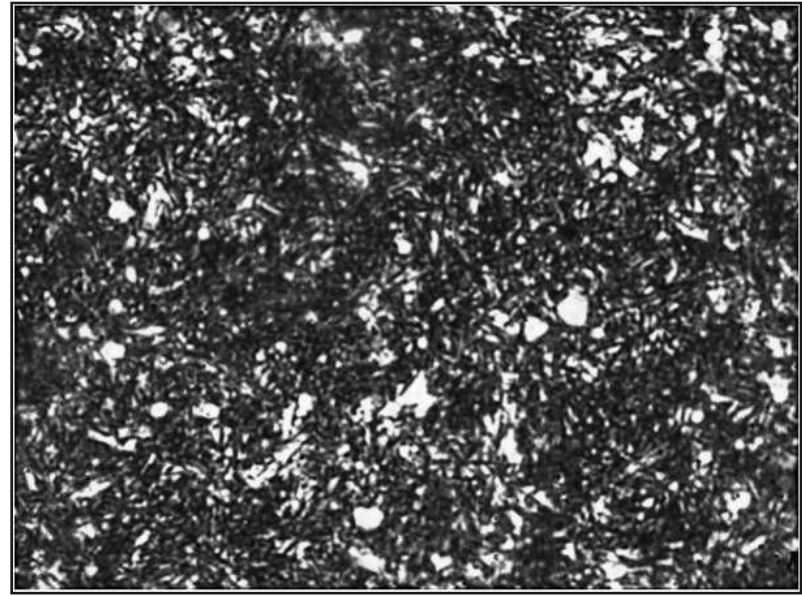

Fig. 4 Microstructure of brand-new drill bit $(A)$, (magnification $\times 1000$, etching: $5 \%$ Nital)

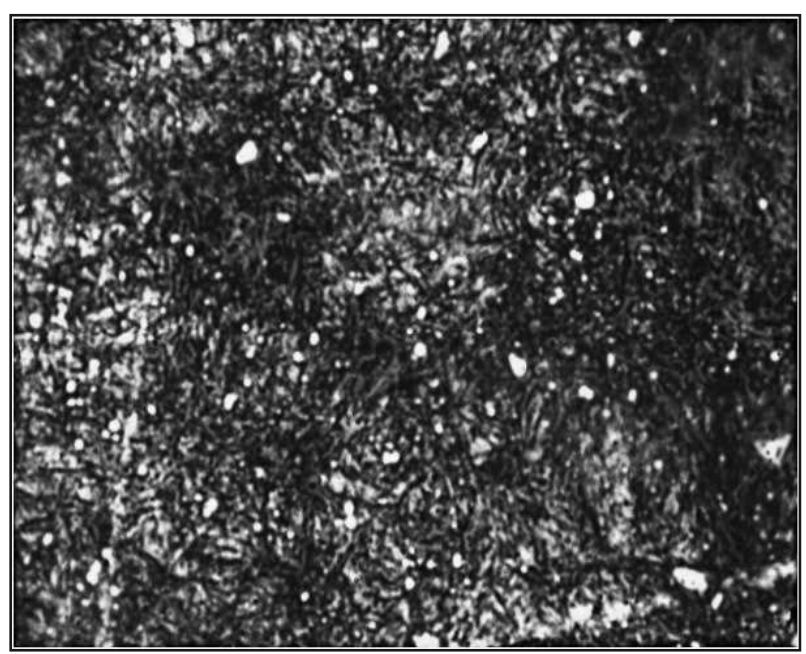

Fig. 5 Microstructure of drill bit (B) worn-out up to 25\%, (magnification $\times 1000$, etching: $5 \%$ Nital)

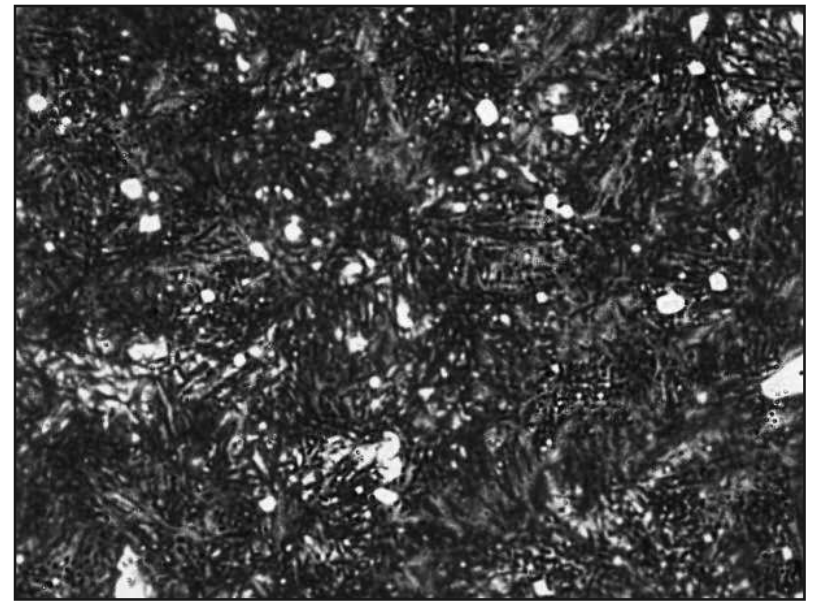

Fig. 6Microstructure of used drill bit (C) - overheated during hole drilling - intended for regeneration, (magnification 1000, etching: 5\% Nital)

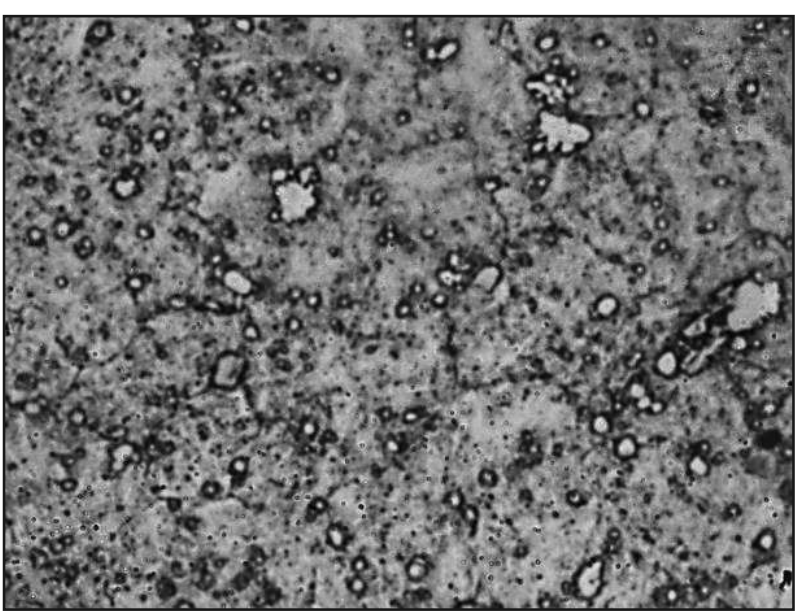

Fig. 7 Microstructure of drill bit (D) used in a hard material - misused (magnification $\times 1000$, etching: 5\% Nital) 
In the next step the material samples were embedded in plastic. Afterwards, its surfaces were polished with sandpapers with progressively finer grit, beginning from 120 and ending at 2500. The next action was to immerse the sample surfaces in water-based alumina $\left(\mathrm{Al}_{2} \mathrm{O}_{3}\right)$ suspension until scratches disappear. Afterwards, the microsections etched with $5 \%$ NITAL reagent were subject to observation.

The photographs of blade surface microstructure were taken by using the Nikon Eclipse E400 microscope with digital image recording. The examples of prepared metallographic microsections and microstructure revealed after etching are presented in Fig. 4-7.

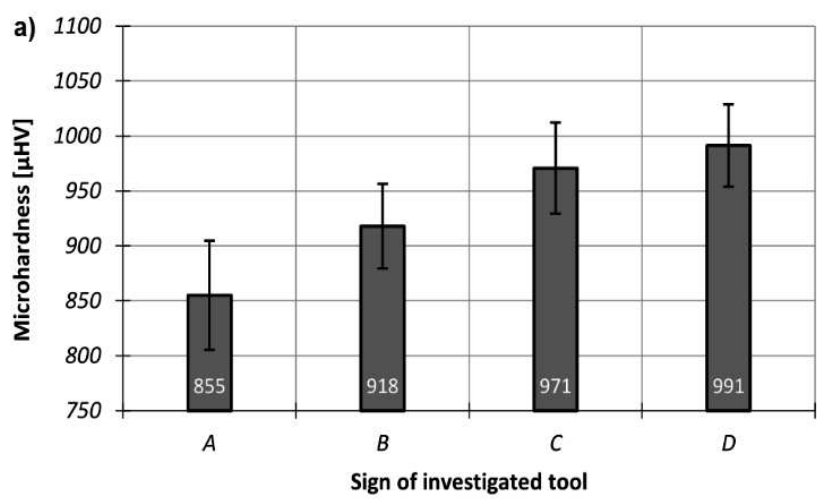

\section{The microhardness measurement in rela- tion to specified wear}

In reference to the varied results obtained microstructure from the surface od edge, the following important step is to measure the microhardness. The measures carried out on the performed mettalographic samples by the use microhardness $(\mu \mathrm{HV})$ tester Future-Tech FM-700. The applied load to tests set at 0.5 $\mathrm{kG}$. In total 16 measurements were made for each sample. The extreme results were rejected (value: $\max$, min). The results of average value and standard deviation are presented in the Fig. 8a, and an orderly distribution of results is presented in the Fig. $8 \mathrm{~b}$.

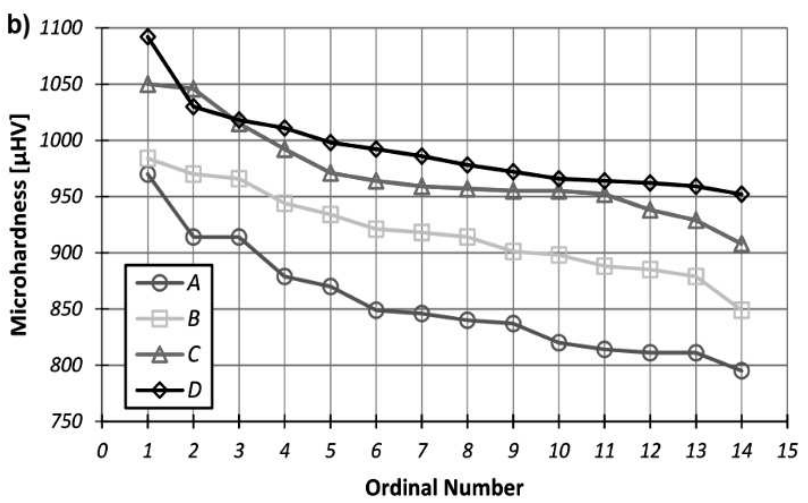

Fig. 8 The measures of microhardness ( $\mu \mathrm{HV})$ : a) average average value and standard deviation, b) distribution of results

The detailed and compared data of measures are presented in the Tab. 5. Based on the carried out experimental tests is possible to determine the difference between $\mathrm{A}$ and $\mathrm{D}$ base on average value microhardness - it is estimated as $\Delta_{\mu \mathrm{HV}}=136[\mu \mathrm{HV}]$. It follows to describe Percentable Wear $\left(\mathrm{PW}_{\mu \mathrm{HV}}\right)$ of tools in the relation to microhardness (2):

$$
P W_{\mu H V}=\frac{\left(\mu H V_{0}-\mu H V_{i}\right)}{\Delta_{\mu H V}} \cdot 100 \%
$$

where: $\boldsymbol{\mu} \boldsymbol{H} \boldsymbol{V}_{\mathbf{0}}$ - value of microhardness of new drill; $\boldsymbol{\mu} \boldsymbol{H} \boldsymbol{V}_{\boldsymbol{i}}-$ consecutive measurements

Tab. 5 The detailed data - summary of measure microhardness from surface cutting tools at certain Production Cycle (PPC).

\begin{tabular}{|c|c|c|c|c|c|}
\hline \multirow{2}{*}{\multicolumn{2}{|c|}{ DESCRIPTION }} & $\mathbf{A}$ & $\mathbf{B}$ & $\mathbf{C}$ & $\mathbf{D}$ \\
\hline & & $P_{P C}=0 \%$ & $P_{P C}=25 \%$ & $P_{P C}=100 \%$ & $P_{P C}=-$ \\
\hline Average of microhardness measure & $\mu \mathbf{H V}$ & 855 & 918 & 971 & 991 \\
\hline Absolute difference of average & $\mu \mathrm{HV}$ & 0 & 63 & 116 & 136 \\
\hline Sdandart deviation & $\mu \mathrm{HV}$ & 50 & \pm 39 & \pm 41 & \pm 37 \\
\hline Absolute difference of standart deviation & $\mu \mathrm{HV}$ & 0 & 11 & 9 & 13 \\
\hline Maximum value & $\mu \mathbf{H V}$ & 795 & 849 & 908 & 952 \\
\hline Minimum value & $\mu \mathbf{H V}$ & 970 & 984 & 1050 & 1092 \\
\hline $\begin{array}{l}\text { Percentable Wear dependent from microhard- } \\
\text { ness } \mathrm{PW}_{\mu \mathrm{HV}}\end{array}$ & {$[\%]$} & 0 & 46 & 85 & 100 \\
\hline
\end{tabular}

$\Delta_{\mu \mathrm{HV}}=136[\mu \mathrm{HV}]$

\section{Discussion of experimental results}

The all obtained results require appropriate discussion. In the first, presented informations in the context of Tab. 5 about number of drilled holes have to be presented in the form of: Time-Life (TL) of total lenght summary depth of drilles holes (TL LENGTH $_{\text {- }}$ equation (3), and total working time of effective wokr expressed in minutes (TL TIME) - equation (4). The de- 
tailed values of mentioned equations above are presented in the Tab. 6. In the mentioned table is considered two modes taking into account the thickness ( $t$ ). Considering of two modes is related with listed materials: reinforcing steel and PVC profiles. The first

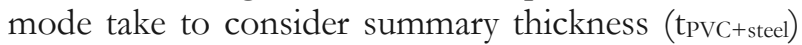
of drilled holes and the second mode take thickness only for steel $\left(t_{\text {steel }}\right)$. These distinctions of material thicnkess are related to hardness of machined materials and dull the edge (decrease sharp cutting edge).
The rationale behind this is that the hardness PVC profiles is several orders of magnitude lower than steel and influence on cutting edge is insignificant - in the effect the PVC is easier material to process in terms of tool wear.

$$
\begin{gathered}
T L_{L E N G T H}=N_{d H} \cdot t \\
T L_{T I M E}=\frac{T L_{L E N G T H} \cdot 1000}{V_{f}}=\frac{T L_{L E N G T H} \cdot 1000}{f_{n} \cdot n}
\end{gathered}
$$

\begin{tabular}{|c|c|c|c|c|}
\hline \multirow{2}{*}{\multicolumn{3}{|c|}{ DESCRIPTION }} & B & $\mathrm{C}$ \\
\hline & & & $P_{P C}=25 \%$ & $P_{P C}=100 \%$ \\
\hline \multicolumn{2}{|c|}{$\begin{array}{l}\text { Percentable Wear dependent from microhardness } \\
\qquad\left(\mathbf{P W}_{\mu \mathrm{HV}}\right)\end{array}$} & {$[\%]$} & 46 & 85 \\
\hline \multirow{2}{*}{$\begin{array}{l}\text { Time-Life }\left(\mathrm{TL}_{\mathrm{LENGTH}}\right) \text { - summary } \\
\text { length of depth drilled holes }\end{array}$} & $t_{\text {steel+PVC }}$ & \multirow{2}{*}[\mathrm{m}]{} & 0.82 & 3.28 \\
\hline & $\mathbf{t}_{\text {steel }}$ & & 0.40 & 1.60 \\
\hline \multirow{2}{*}{$\begin{array}{l}\text { Time-Life (TL } \text { TIME }_{\text {TI }} \text { - summary time } \\
\text { of drilling }\end{array}$} & $t_{\text {steel+PVC }}$ & \multirow{2}{*}{ [min.] } & 7.74 & 30.66 \\
\hline & $\mathbf{t}_{\text {steel }}$ & & 3.77 & 15.09 \\
\hline
\end{tabular}

Tab. 6 The detailed data - summary of measure microhardness from surface cutting tools.

In reference to Tab. 6 visible is almost two-fold difference of TLLENGTH and TLTIME. The main reason of these values is lenght of the hole. The difference of thickness between materials taken to calculations is equal to $2.1 \mathrm{~mm}$ - however, it does not bring significant differences in the results, which allows us to state that the thickness of the steel has a predominant influence on the length of the tool's operation, in relative to the PVC profle. Therefore, when considering the Time-Life (TL) of HSS drills and the similar thickness of the materials mentioned, the thickness of the PVC profile may be ignored. In summary, the most reliable measurement for this type of calculation is to assume a constant thickness - in this case $4.1 \mathrm{~mm}$ with distinctions on $t_{\text {steel }}$ and tpvC and to state the number of made holes.

The experimental examinations were focused on the drill bit cutting edge and applied to its microstructure. Microstructure of brand-new drill bit (A) is presented in Fig. 5. This microstructure is constituted of martensite with unevenly distributed visible carbides of different size in the form of bright individual spots with globular-like shape. The next results of material examination (drill bits B, C) are shown in Fig. 5-6. Presented results of microstructure changes arisen in effect of drilling holes. According to the results presented in [29, 30, 31], it can be assumed that locally on a small surface area of drill bits B and C - in the Fig. 5-6 is noticeable color changes in the relation to new drill bit (A). The changes are caused primarily by temperature effect and heat generated during tool operation. Microstructure (B) presented in Fig. 5 (microscopic image) reveals local slight changes related to the presence of tool overheating zones (dark blue colour). Dark blue islands form small clusters on the microstructure surface (drill bit B). The next microstructure (drill bit C) presented in Fig. 6 shows more distinct presence of overheating zone. This results from longer drill operating time, thus greater amount of heat generated.

A special case is the misused drill bit $\mathrm{D}$ because of quite different nature of the obtained microstructure. During test drilling, the drill bit was slightly deformed at the cutting zone, thus indicating a very high working temperature. The revealed microstructure for drill bit D (Fig. 7) according to description contained in [32] represents ferritic microstructure with primary and secondary carbides mainly precipitated at the ferrite grain boundaries.

For the measure of microhardness of cutting surfaces the worth of observe is the increase the microhardness in evry in each of the following stages $(B, C$, $\mathrm{D})$ in the relation to microhardness of the new drill (sample A). The smallest differences between each other concern tools marked as A-B and C-D. Although small amount of data, based on the mentioned results it can attempt approximate the maximum value of Percentable Wear dependent from microhardness $\left(\mathrm{PW}_{\mu \mathrm{HV}}\right)$ dependent on the Production Cycle (P $\left.\mathrm{PC}\right)$. The Fig. 9a contains trend line of logarithmic function with good fitted to experimental which describe Rsquared value. Due to the inability designate a trend line for $\mathrm{x}=0$, value of Percentage of Production Cycle $(\mathrm{PPC})$ was set as $0,125 \%$ which corresponds to first drilled hole. In the Fig. 9b presented approximate results to obtain maximum tool wear limit value of $\mathrm{PW}_{\mu \mathrm{HV}}-$ which is result of sample $\mathrm{D}$. The computations indicate the value of $\mathrm{P}_{\mathrm{PC}}=327 \%$ - which corresponds to the value 2616 drilled holes (drill bit D). For information, it can be indicated that the approximated value for $\mathrm{PPC}_{\mathrm{PC}}=25 \%$ is $\mathrm{PW}_{\mu \mathrm{HV}}=54 \%$ (drill bit $\mathrm{B}$ ) and for $\mathrm{P}_{\mathrm{PC}}=100 \%$ is $\mathrm{PW}_{\mu \mathrm{HV}}=79 \%$ (drill bit C). The absolute 
value of the difference for mentioned approximatly results versus experimental results are following:

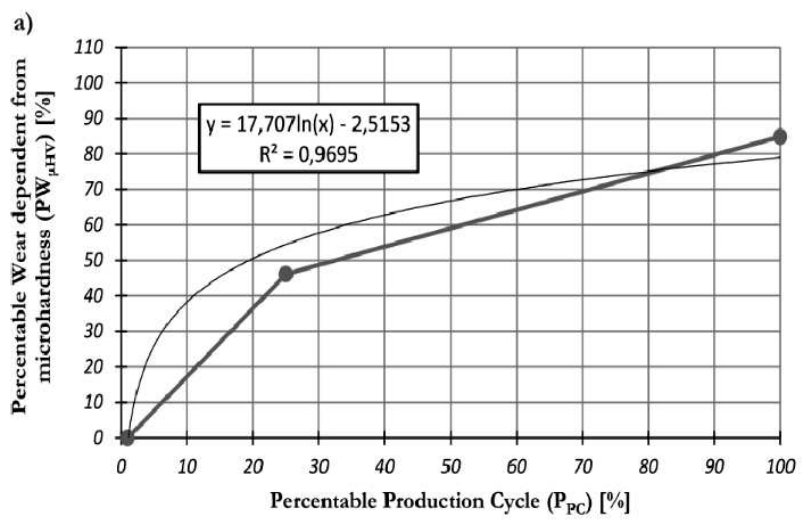

$\mathrm{P}_{\mathrm{PC}}=25 \%$ is $8 \%$ (drill bit $\mathrm{B}$ ) and for $\mathrm{P}_{\mathrm{PC}}=100 \%$ is $6 \%$ (drill bit C).

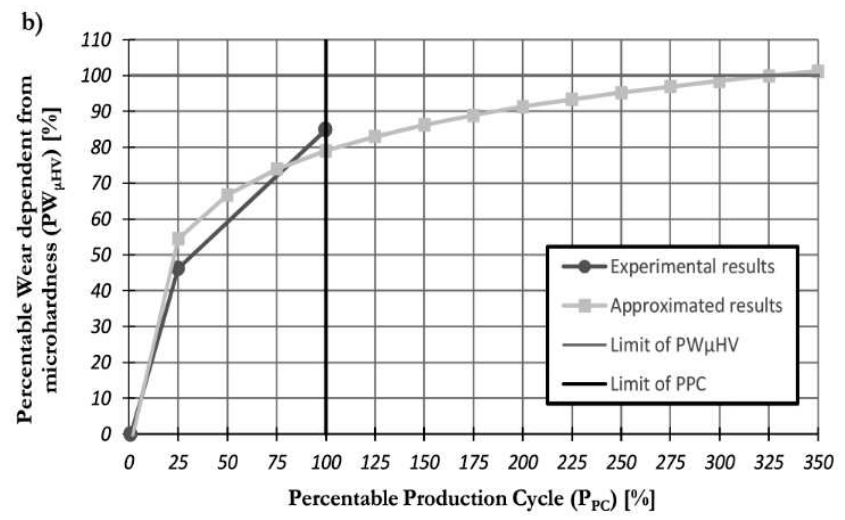

Fig. 9 Percentable production cycle (PPC) versus Percentable Wear dependent from microhardness ( $\left.P W_{\mu H V}\right)$ for: a) designation of trend line with R-squared value; b) Approximated results for maximum $P_{W_{\mu H V}}$ dependent by the $P_{P C}$

\section{Conclusions}

The discussion of obtained results as well as literature review allow the following conclusions related to the obtained results in the form of parameters of cutting process, microstructure images and microhardness of drill bits under investigation.

The drill bit wear rate and type (e.g. dulling, buildup edge formation, chipping) affected by hole drilling process parameters (e.g. cutting speed). Proper selection of said parameters decides also on proper drilled hole quality. In turn, the degree of drill bit wear has an effect on both drilled hole quality and drilling process efficiency. Therefore, attention should be paid to that the use of worn-out drill bits lest a detrimental impact on economic aspects, thus resulting in higher production costs.

The tested drills bits (HSS) are used for drill holes in rigid PVC profiles reinforced by hot-dip galvanized steel channel section. Their Time-Life drills is dependent of thickness steel reinforcement, which cause main wear of tool. The decisive factor in this case is the steel hardness value, which is several orders higher than that of the PVC profile. The values of these hardnesses are incomparable - they cannot be compared with each other. Additionally, it has to be indicated that the thicknesses of the machinning materials are very similar. Generally, for the presented variant, it can be assumed that at what PVC thicknesses its influence on the degree of wear can be neglected.

It has been assumed that, the number of drilled holes cause rising of temperature. In the effect the generated heat cause changes in microstructure on its cutting edges. The research conducted shows that the drill bits under consideration have the different microstructures in various phases of tool usage and wear, thus confirming that drill bit microstructure alters with increasing degree of wear.
In the area of research interest also remains the issue of tool microhardness changes in different stages of wear. Carried out experimental tests indicate that the tool hardness increasing with a Production Cycle. Probably, together with properly supplied amount of heat precipitation of secondary carbides can locally affect (due to its hardness) slower tool wear rate. This phenomena is visible in the Fig. 9a between points of experimental tests. The sudden wear is progressive in the first stage of value $\mathrm{P}_{\mathrm{PC}}$ between from 0 to $25 \%$, and slow down from $25 \%$ to $100 \%$. As a result, it can be assumed that the greatest dulling of the drill occurs in the first phase of the process. Then, the unfavorable changes of geometry blades are fixing by the increasing of microhardness. The deformed cutting surface begins to "slide" on the surface more than cutingt it as a result, the temperature of the process and the amount of generated heat increases, which negatively affects into changes in the microstructure and properties of the tool material.

The approximated results indicate on the very slow process od degradation tools after the excidding $\mathrm{P}_{\mathrm{PC}}$ $100 \%$. For mentioned result the $\mathrm{PW}_{\mu \mathrm{HV}}$ is $85 \%$ (drill bit $\mathrm{C}$ ). The assumptions made show that the value $\mathrm{PW}_{\mu \mathrm{HV}}=100 \%$ can be reach at $\mathrm{P}_{\mathrm{PC}}=327 \%$ - what is 2616 numbers of drilled holes (drill bit D).

Another issue to be considered is determination of the percentage of different carbides present in various stages of drill bit wear. A detailed theoretical analysis could enables us to estimate the percentage of carbides and determination of the percentage of carbide types in a given phase of wear while considering electron affinity of elements - conditioned by an accurate knowledge of the complete chemical composition of the cutting tool. Perhaps this is the explanation of the obtained values of the standard deviation.

These researches includes only HSS tools. Other 
materials used in cutting tools may have a different behaviour with respect to the mode of wear and microstructural changes. This results for, e.g. properties shaped indi-vidually during manufacturing process of the tool intended for dedicated cutting operations (turning, milling, etc.). An important aspect is to determine the tool wear limit at which it loses its performance. This translates in-to deterioration of drilled hole quality in the form of dimensional errors, roughness parameters as well as other economic, technological and toughness aspects. Failure to ensure a proper predefined surface rough-ness level may affect mating of parts. This may lead to premature wear and jamming of machine parts. Thus, it is necessary to determine when the tool reaches the wear limit to decide on tool selection with regard to its sufficient quality. An appropriate solution seems to be developing a model in which based on specified input values it will be possible to find an answer regarding the tool wear limit. Feedback will then enable to determine the last phase of allowable wear and the time when the tool is taken out of service. Potencial possibility of extending the working time of the tool based on the use cooling fuild - this solve effectively dissipates heat, but not eleminate totally dulling process, however delays the wear.

Summarizing, the conducted research is helpful for keeping a rational tool management in a manufacturing plant regarding, for example, worn-out tool removal and regeneration or the purchase of new ones (in a plant or corporation), whichever is cost-effective.

\section{Acknowledgement}

Publication financed by the subsidy granted to the Cracow University of Economics.

Especially thanks for the production company OknoPlus Sp. z o.o. Zgodna 55, 30-444 Kraków from Poland for cooperation in the field of technical issues and enable the publication of selected data.

\section{References}

[1] ULEWICZ, R., NOVY, F. R. (2016). The influence of the surface condition on the fatigue properties of structural steel. In: Journal of the Balkan Tribological Association, 22(2, 1), pp. 11471155.

[2] ASHBY M., SCHERCLIFF H., CEBON D. (2011). Inżynieria Materiałowa - Tom 2, pp. 200216. Wydawnictwo Galaktyka, Łódź. ISBN: 978-83-7579-206-5.

[3] KOL. RED.: KOCAŃDA S., KOCH E., KULESZA C., LUTOWSLAWSKI Z., OCHĘDUSZKO K., RYTEL Z., SZOPSKI K. (1970). Poradnik Inzyniera
Mechanika-Tom 3, Zagadnienia Technologicæne, pp. 811-849 (in Polish). Wydawnictwo NaukowoTechniczne.

[4] FELD M. (2003). Podstawy projektowania procesów technologicznych typowych cześci maszyn, Wydawnictwo Naukowe PWN, Warszawa. ISBN: 978-83-01-19761-2.

[5] PIRTINI, M., LAZOGLU, I. (2005). Forces and hole quality in drilling. In: International journal of machine tools and Manufacture, No. 45(11), pp. 1271-1281.

[6] NOWAKOWSKI Ł., MIKO E., SKRZYNIARZ M. (2016). Ocena dokładności wymiarowo-kształtowej otworów wierconych wiertłami składanymi. In: Mechanik, No. 08/09.

[7] WARTACZ, A., ŚWIĆ, A., ZUBRZYCKI, J. (2004). Zużycie ostrza narzędzia, a zmiana parametrów toczenia w kolejnych zabiegach. In: Eksploatacja i Niezawodność, No. 4, pp. 58-61.

[8] JAWORSKI, J., KLUZ, R., TRZEPIECIŃSKI, T. (2016). Operational tests of wear dynamics of drills made of lowalloy high-speed HS2-5-1 steel. In: Eksploatacja i Niezawodność, Vol. 18, No: 2.

[9] JAWORSKI, J., KLUZ, R., TRZEPIECIŃSKI, T. (2014). Wpływ parametrów obróbki na miejsce powstawania zużycia i intensywność procesu zużywania wierteł. In: Tribologia, Vol. 45, pp. 81-90.

[10] DOBRZANSKI L. A. (2004), Metalowe materiaty insynierskie, Wydawnictwo Naukowo Techniczne, Gliwice, ISBN: 83-204-3045-3.

[11] IPILAKYAA T. D., TULEUN L. T., GUNDU D. T. (2017). Comparative Study on the Effect of Cutting Fluids on the Flank Wear of High Speed and Carbide Tipped Cutting Tools. In: International Journal of Trend in Scientific Research and Development (IJTSRD), Vol. 1, No. 4, pp. 458-465.

[12] NAGESWARA R. D., VAMSI K. P. (2008). Performance Profiling of Boric Acid as Lubricant in Machining. In: Journal of the Brazilian Society of Mechanical Sciences and Engineering. Vol. XXX, No. 3, pp. 239-244.

[13] OSARENMWINDA J. (2014). Effect of Cutting Fluids on the Flank Wear of High Speed and Carbide Tipped Cutting Tools. In: Journal of Applied Sciences and Environmental $M a$ nagement, Vol. 18 (2), pp. 159-163.

[14] NANDGAONKAR S., GUPTA T. V. K., JOSHI S. (2016). Effect of water oil mist spray (WOMS) cooling on drilling of Ti6Al4V alloy 
using Ester oil based cutting fluid. In: Procedia Manufacturing, Vol. 6, pp. 71-79.

[15] SODERBERG S., HOGMARK S. (1986). Wear mechanisms and tool life of high speed steels related to microstructure. In: Wear, Vol. 110, Issues 3-4, pp. 315-329.

[16] AZIZPOUR M. J., MOHAMMADI H. M. (2010). Wear Mechanisms in High Speed Steel Gear Cutting Tools, In: World Academy of Science. In: Engineering and Technology International Journal of Materials and Metallurgical Engineering. Vol. 4, No 9.

[17] DINIZ A. E., MACHADO A. R., CORRÊA J. G. (2016). Tool wear mechanisms in the machining of steels and stainless steels. In: International Journal of Advanced Manufacturing Technology. Vol. 87, pp. 3157-3168.

[18] ELKASEER A.M., POPOV K.B., DIMOV S.S., MINEV R. (2011). Material Microstructure Effect-based Investigation of Tool Wear in Micro-endmilling of Multi-phase Materials. In: Proceedings of the 7 th International Conference on Multi-Material Micro Manufacture. pp. 188-192. ISBN: 978-981-08-6555-9.

[19] ELMAGRABI N.H., SHUAEIB F.M., HARON C.H.C. (2007). An overview on the cutting tool factors in machinability assessment, In: Journal of Acbievements in Materials and Manufacturing Engineering. Vol. 23, Issue 2, pp. 87-90.

[20] JEMIELNIAK K. (1998). Obróbka skrawaniem, Wydawnictwo OWPW, ISBN: 978-83-7814839-5.

[21] LYSZKOWSKI R., ZARAŃSKI Z. (2018). Zusyycie $i$ trwatosíc ostrza - technologie materiatón konstrukcyjnych $i$ wielofunkecyjnych, Wojskowa Akademia Techniczna, Warszawa.

[22] SZATANIAK, P., NOVY, F., ULEWICZ, R. (2014). HSLA steels - Comparison of cutting techniques. In: METAL 2014 - 23rd International Conference on Metallurgy and Materials - Conference Proceedings, pp. 778-783.

[23] KYNCL L., SADÍLEK M., ČEP R., PETRŮ J., STANCEKOVA D., PROCHÁZKA J., NOVÁČEK P. (2014). Tests of Drills during Drilling Holes into Alloy Wheels, In: Manufacturing Technology, Vol. 14(4), pp. 554-561.

[24] PODANÝ J., TOMÍČEK J. (2020). Analysis of small holes manufacturing for optomechanical components, In: Manufacturing Technology, Vol. 20(2): pp. 229-236.

[25] AHUJA I.P.S., KHAMBA J.S. (2008). Total productive maintenance: literature review and directions. In: International Journal of Quality \& Reliability Management, Vol. 25, No. 7, p. 720.

[26] https://leanactionplan.pl/tpm/- acess: 29 October 2020.

[27] https://www.oknoplus.com.pl - acess: 29 October 2020.

[28] http://www.matweb.com - acess: 15 February 2021.

[29] BRILL T. B. (1980). Light: Its Interaction with Art and Antiquities, Plenum Press, New York. ISBN: 978-0-306-404-16-0.

[30] ANDREWS J. (1994). New Edge of the Anvil: A Resource Book for the Blacksmith, Skip Jack Press, Chicago, ISBN: 978-0-878-57186-4.

[31] DYRBUŚ G., LIS K. (2014). Pomiar temperatury wiertła krętego metoda pirometryczna, In: Insyznieria Maşyn, Vol. 19, No. 1, pp. $78-88$.

[32] SUT, M. (2010). Analysis of the property of steel $S W 7 M$ and $S W 18$ after gas nitriding process and annealing, Engineering Thesis. Warsaw University of Technology - Faculty of Material Engineering, Warszawa. 